\title{
The Possibility of Integrating the Disaster Preparedness in Physical Education Curriculum
}

\author{
Soni Nopembri*, Saryono Saryono \\ Department of Physical Education \\ Universitas Negeri Yogyakarta \\ Yogyakarta, Indonesia \\ *soni_nopembri@uny.ac.id, saryono@uny.ac.id
}

\author{
Mitta Kurniasari, Yuli Nurmalasari, Diana Septi \\ Purnama \\ Department of Educational Psychology and Guidance \\ Universitas Negeri Yogyakarta \\ Yogyakarta, Indonesia \\ mittakurniasari@uny.ac.id, yulinurmalasari@uny.ac.id, \\ dianaseptipurnama@uny.ac.id
}

\begin{abstract}
Being prone to impacts of natural disasters, Indonesia needs to increase the preparedness of Indonesian people through various means, including the education curriculum approaches. The physical education curriculum enables children to develop physical, psychological, social, and spiritual preparedness. Therefore, the aim of this study was to investigate the possibility of integrating the disaster preparedness into the physical education curriculum in Indonesia. The qualitative research approach with Grounded theory design was used. Data collection was carried out through in-depth interviews and FGD (Focus Group Discussion). The FGD was conducted with non-government organizations (NGO) that involved in disaster management in Indonesia, while in-depth interviews were conducted with government and international institutions. Data analysis was performed by using a systematic and standard format of grounded theory approach, which included open, axial, and selective coding. The analysis showed that the disaster preparedness program was not yet optimal in involving the school. There was no integration of preparedness program with the existing curriculum. In addition, it is possible to integrate the disaster preparedness into the Physical Education curriculum. It can be concluded that the integration of the disaster preparedness into physical education curriculum needs more concepts that are comprehensive by involving various parties. School involvements in developing an integrated physical education curriculum with the disaster preparedness needs to be appropriate to the specifics, characteristics, and the conditions.
\end{abstract}

Keywords: curriculum, disaster, preparedness, physical education

\section{INTRODUCTION}

Indonesia is one of disaster-prone countries. Consisting of thousands of islands and dominated by seas, the country has to cope with the constant risk of disasters, particularly earthquakes, structure fires, tsunami, floods and flash floods, landslides, as well as volcanic eruptions [1]. The motion of the plates beneath Indonesian islands causes earthquakes. Similarly, volcanic eruptions occur as the country sits on the Pacific "Ring of Fire", home to numerous active volcanoes including Merapi, Sinabung, and Kelud mountains. According to the map in Indonesian disaster risk indexes from 1815 to
2012, most areas of the country, especially Sumatera, Java, Sulawesi, and Borneo, are at high risk to multiple disasters.

The potentials and disaster threats are affecting people's lives. According to Ronholt, Karsberg, \& Elklit [2], disasters affect all people. The effects include the negative psychological and social impacts on children [3-7]. In addition, to recover from a disaster, people need certain level of spirituality to help them in the process of psychological reinforcement $[8,9]$. Children who are affected by disasters need long-term social supports and mental health as well as comprehensive preparedness intervention [4]. Therefore, it becomes necessary to develop long-term disaster preparedness through formal and non-formal education to help mitigate the negative impacts of disaster on children.

Numerous studies have revealed empirical evidence suggesting the physical, psychological, social, and spiritual benefits of regular physical activities in physical education among children and youth [10-12]. In addition, physical education is the only subject in the curriculum which is related to improvement of physical, psychological, social, and spiritual health of the students [10-13]. In particular, playing activities can help children learn from various positive experiences to eliminate negativity within themselves $[6,14,15]$. Designing physical education curriculum systematically and structurally and integrating it with disaster preparedness will significantly help children face the emergencies.

This far, there has been no review examining the existence of physical education and sports curriculum as part of disaster preparedness development. Previous studies conducted by Nopembri, Saryono, and Rithaudin [16-18] focused solely on the development of effective learning model to improve psychosocial and spiritual health among children in disasterprone zone in Merapi Yogyakarta. Therefore, this study aims to investigate the possibility of physical education curriculum to integrate with children's physical, psychological, social and spiritual preparedness in facing disasters in Indonesia.

\section{MethodS}

The grounded theory design is a set of procedure used in theory construction to describe the process of a substantive 
topic [19]. The grounded theory works best at describing phenomena or process as well as constructing a general theory of a phenomenon that is impossible to be described using the existing theories. Data were collected using an FGD (Focus Group Discussion) and in-depth interviews. FGD aimed at eliciting pictures of problems related to the implementation of disaster education as well as obtaining solutions to the problems. Several representatives from Non-Government Organizations (NGOs) such as HOPE Indonesia (HI), Plan International Indonesia (PII), Aksi Cepat Tanggap (ACT), and Masyarakat Penanggulangan Bencana Indonesia (MPBI) took part and spoke in this FGD. Interviews were conducted to provide information related to the prevailing policies and programs and involving an international organization (UNICEF) and government organizations such as The Ministry of Education and Culture (MoEC), Yogyakarta Special Region (DIY) and West Java Education Offices, Badan Nasional Penanggulangan Bencana (BNPB), and Badan Penanggulangan Bencana Daerah (BPBD) of DIY and West Java. In addition, researchers also conducted studies on document relevant to the curriculum and disaster preparedness.

In a grounded theory research, data analysis was conducted systematically based on certain standard format [19]. Open coding refers to initial categorization of information related to the phenomena being studied. This process was done by breaking up data into segments to form subcategories. Axial coding, on the other hand, is data assembly presented in form of coding paradigm or logic diagram in which researchers identify central phenomena (central category of a phenomenon), exploring causal conditions (categories affecting the phenomena), specifying strategies (actions or interactions resulting from central phenomena), identifying context and mediating conditions (broad or and narrow conditions influencing the strategy), and describing consequences (results of the strategy) of the phenomena. Selective coding is the process of identifying the "story line" and writing the story, which integrates categories into one axis-coding model. In this phase, hypotheses are usually presented.

\section{RESULTS AND DISCUSSION}

\section{A. Preparedness Program That Involves Schools}

It was found that a number of schools have been generally involved in the implementation of disaster preparedness program initiated by some NGOs. This program, however, has not been implemented in all areas in the country. "The Disaster Alert School Program has been run in 11 Primary Schools across Indonesia. These 11 schools are all fostered by PT. Trakindo Utama" (HOPE, FGD, May 19th, 2019). "Preparedness at school is lower than that in the community" (ACT, FGD, May 19th, 2019). "The Ministry of Education has not assigned or fostered any school as a pilot school to conduct disaster preparedness education. There is only one Special School (SLB) fostered by the government, other schools, on the other hand, are fostered by NGOs (MoEC, Interview, May 20th, 2019).

The existing Disaster Alert Schools have been equipped with disaster preparedness program. However, school resources, including the principals and the teachers, have not optimally supported the implementation of the program. "There are three main programs in a Disaster Alert School including knowledge sharing, skill-up, and watching disaster videos together. Unluckily, skill improvement through implementation of the three programs has not been fully supported by the school, particularly the school principals and the teachers. Training has always been focusing on the students" (ACT, FGD, May 19th, 2019). "Disaster preparedness program at school solely involved physical education and art teachers and was run in form of school in the box activity only" (PII, FGD, May 19th, 2019). "Disaster preparedness requires maximum mental readiness to reduce the number of victims at school. Therefore, all school members should take parts and be all-out in running the program (HI, FGD, May 19th, 2019).

The promotion of disaster preparedness program remained challenging due to the lack of coordination between the Education Office and local BPBD. The following FGD statement supports the above finding, "The government has made mistakes in advocating preparedness program. According to BPBD, the secretariat of safe schools should have been under BPBD considering their main responsibilities in implementing disaster preparedness" (PII, FGD, May 19th, 2019). "The concept of Disaster Risk Education, particularly related to safe school secretariat, among government agencies remained unclear" (ACT, FGD, May 19th, 2019). "According to BNPB, Safe School works under Directorate of Disaster Risk Reduction, under Mitigation subunit; meanwhile, according to the Ministry of Education and Culture, it belongs to the safe part of PKLK (Special Education and Special Service) project, a collaboration between BNPB and the Ministry of Education and Culture to manage Safe School" (BNPB, WCR, May 20th, 2019).

\section{B. Integrated Program of Preparedness and Curriculum}

The second focus of the study is to observe the integration of disaster's preparedness into the current curriculum. Based on FGD result and interviews, there is no integration of disaster's preparedness into the current curriculum. "Actually, the awareness of disaster's preparedness also needs to be integrated into the curriculum in higher education by conducting a course on disaster's preparedness, or a program on disaster education could be included in community service." (HI, FGD, May 19th, 2019). "There has not been an integrated curriculum made by The Ministry of Education and Culture on Disaster's Preparedness Education or what is called Satuan Pendidikan Aman Bencana (SPAB)" (MoEC, Interview, May 20th, 2019). "BNPB has not had any concept of how to integrate disaster matters into curriculum" (BNPB, Interview, May 20th, 2019). "Disaster curriculum in West Java Province started off with the President's instruction and resulted in Pelajar Siaga Bencana (Students Alert to Disasters) by BPBD, Education Department, and Armed Force. However, disaster curriculum has not been integrated in either disaster resilience schools or other schools" (West Java Education office, FGD, May 23rd, 2019).

Disaster integration into the current curriculum is important, considering that Indonesia is in a location prone to disasters. NGO and some related departments have many materials on disaster preparedness but they are not organized 
well to be in curriculum yet. "There are many materials on disaster preparedness. School is a place to ensure safety for kids when a disaster occurs where they live. Education on disaster preparedness is a life skill for students" (ACT, FGD, May 19th, 2019). "SPAB in Education comes with a big challenge because a disaster that does not directly affect the society is considered unimportant" (PII, FGD, May 19th, 2019). "There needs to be an interest the do's and don'ts when a certain disaster occurs. Disaster preparedness requires a maximum mental preparedness to reduce the number of casualties at school. In East Indonesia, disaster awareness is high, but the awareness to be prepared for disasters is unfortunately still low" (HI, FGD, May 19th, 2019).

The importance of integrated curriculum is also agreed upon by some NGOs, institutes, and related departments and they have made some plans, though they have not been socialized well. School is the right choice to be the first place to socialize preparedness. This is in line with the statement "ACT is concerned on some matters related to disaster preparedness, such as integrating disaster preparedness into formal curriculum, how students can still study even if a disaster occurs, and preparing students with mild or severe psychosocial tendency". "Disaster mitigation into curriculum will be a part of the national curriculum and it will not be a course. There will be an online training on disaster resilience schools for teachers and non-teachers." (PII, FGD, May 19th, 2019). "BPBD DIY also encourages the Education Department to encourage schools to include materials on disaster accordingly" (BPBD DIY, Interview, May 20th, 2019). "BPBD West Java's programs in disaster preparedness are to decrease vulnerability by improving facilities; giving education, socialization, and simulations to every governmental institutions and schools; spreading awareness on disaster preparedness" (BPBD West Java, Interview, May 23rd, 2019).

\section{Possibility to Integrate Preparedness in the Physical Education Curriculum}

The third focus of this study is the possibility to integrate preparedness into the Physical Education curriculum. Physical Education is an ideal class to be integrated with preparedness considering that there are many physical activities involved in the class. "Kids at post-disaster shelters prefer outdoor sports to studying in the shelters. We can identify what sports are proper to do in disaster-prone situations" (MPBI, FGD, May 19th, 2019). "Disaster resilience curriculum is integrated into extracurricular activities, scouts, or simulations, cooperating with BPBD, MD MC" (DIY Education Office, Interview, May 20th, 2019).

Disaster preparedness integration into the Physical Education curriculum are in a form of outdoor activities. With that possibility, preparedness integration into the curriculum can also be applied in several models. The models are in line with the statement, "To make a school curriculum is done by making modules, multiracial step-by-step posters that could be used in any region and by anyone. PRB explains how people will not have any difficulty after disaster. And PRB contains materials on how kids are friends with nature." (HOPE, FGD, May 19th, 2019). "Curriculum must include the culture of changing attitude/lifestyle in facing disaster and be individual- based, that each person should know what to do in a disaster" (ACT, FGD, May 19th, 2019). "BPBD DIY shares knowledge on disaster preparedness through learning activities, socialization, discussions, pamphlets, posters, radio, TV, shadow puppet shows, and others" (BPBD DIY, Interview, May 20th, 2019).

Supports from NGO, institutions and related departments of preparedness curriculum integration is very big. The role of policymakers, which is the Government, is highly expected in order for the curriculum to be integrated well with disaster preparedness in schools across Indonesia. "To run the Disaster program in schools, UNICEF has Safe School program, which has a special team to ensure that Safe School runs even in small regions by cooperating with MoEC, BNBP, and NGO in Joint Secretary. The programs in UNICEF Indonesia also refer to the programs of UNICEF Global related to Disaster Management" (UNICEF, Interview, May 20th, 2019). "E-learning on disaster is available on simpatik.belajar.kemendikbud.go.id. It requires an ID Card and NPWP to log in" (MPBI, FGD, May 19th, 2019). "Disaster preparedness education was centered at Subdit Pendidikan Khusus \& Layanan Khusus (PKLK) located in Cipete, South Jakarta, but now it has been transferred to Subdirectory in MoEC" (MoEC, Interview, May 20th, 2019). "In giving a program to schools or others, BPBD refers to Minister and Governor Regulations that are valid at the time in order to run the program" (BPBD DIY, Interview, May 20th, 2019).

NGO and related departments are currently preparing their disaster preparedness programs. Those programs are to be socialized in some subject of curriculum. This is in line with the interview with FGD. "The latest program uses scout extracurricular to conduct education on disaster preparedness. Scout activities will integrate PRB programs and there will be Training of Training for 5 days. PRB Programs, collaborating with mosque councils in Indonesia, will make lectures on disasters. There are some Health higher education which do community service (KKN) to focus on SPAB. SPAB Elearning are available on National Secretary" (BNPB, Interview, May 20th, 2019). "BPBD DIY provides disaster preparedness modules in a form of up-to-date books. Modules are only available in soft files and can be accessed on INARISK (an app)" (BPBD DIY, Interview, May 20th, 2019). "Right now, the Education Department is working on disaster mitigation curriculum integrated into Geography" (West Java Education Office, FGD, May 23rd, 2019).

\section{CONCLUSION}

Based on the analysis result, it could be concluded some finding in this study. Disaster preparedness program has not optimally involve the schools. There has been no disaster preparedness program integrated into the current curriculum. There is a possibility to integrate disaster preparedness into the Physical Education curriculum. There has been no safe school pilot in Indonesia. The socialization of disaster resilience does not draw enough attention from schools. There is a difference in opinion between the government and related institutions on school secretary of disaster resilience. There has been no evaluation on socialization of disaster preparedness in schools. 


\section{ACKNOWLEDGMENT}

The authors would like to thankful for Ministry of Research, Technology, and Higher Education of Republic of Indonesia for funding this work.

\section{REFERENCES}

[1] BNPB, Buku Pedoman Latihan Kesiapsiagaan Bencana: Membangan Kesadaran, Kewaspadaan, dan Kesiapsiagaan dalam menghadapi Bencana. Jakarta: Direktorat Kesiapsiagaan, Deputi Bidang Pencegahan dan Kesiapsiagaan, Badan Nasional Penanggulangan Bancana, 2017.

[2] S. Ronholt, S. Karsberg, and A. Elklit, "Preliminary evidence for a classroom based psychosocial intervention for disaster exposed children with posttraumatic stress symptomatology," Child Youth Care Forum, vol. 42, pp. 617-631, 2013.

[3] R. Mondal, et al., "Acute stress-related psychological impact in children following devastating natural disaster, the Sikkim earthquake (2011) India," Journal of Neuorsciences in Rural Practice, vol. 4, pp. 19-23, 2013.

[4] M. Uemoto, A. Asakawa, S. Takamiya, K. Asakawa, A. Inui, "Kobe earthquake and post-traumatic stress in school-aged children," International Journal of Behavior and Medicine, vol. 19, pp. 243-251, 2012.

[5] E.Z. Kilic, H.D. Ozguven, and I. Sayil, "The Psychological effects of parental mental health on children experiencing disaster: The experience of Bolu earthquake in Turkey". Family Process, vol. 42, pp. 485-495, 2003.

[6] N. Kar, "Psychological impact of disaster on children: Review of assesment and interventions," World Journal of Pediatric, vol. 5, pp. 511, 2009.

[7] T. Yonekura, S Ueno, and T. Iwanaka, "Care of children in a natural disaster: Lesson learned from the great East Japan earthquake and tsunami," Pediatric Surgery International, vol. 29, pp. 1047-1051, 2013.

[8] R.E. Dew, S.S. Daniel, D.B. Goldston, W.V. McCall, M. Kuchibhatla, C. Schleifer, M.F. Triplett, and H.G. Koenig, A prospective study of religion/spirituality and depressive symptoms among adolescent psychiatric patients. Journal of Affective Disorders, vol. 120(1-3), pp. 149-157, 2010.
[9] B.C. Hernandez, The religiosity and spirituality scale for youth: development and initial validation (Doctoral Dissertation). The Department of Psychology, the Graduate Faculty of the Louisiana State University and Agricultural and Mechanical College, Louisiana, 2011.

[10] B.F. Piko, and N. Kereztes, "Physical activity, psychosocial health and life goals among youth, " Journal of Community Health, vol. 31, pp. 136-145, 2006.

[11] M. Curelaru, B. Abalasei, and M. Cristea, "Psychosocial correlates of the need for physical education and sports in high school," Journal of Social Sciences, vol. 7, pp. 521-528, 2011.

[12] S. Morrison, and R. Nash, "The Psychosocial Influences on Participation Rates within Secondary School Physical Education," Journal of Physical Education and Sport (JPES), vol. 12(2). Art 24. pp.147 - 156, 2012.

[13] K. Lodewyk, C. Lu, and J. Kentel, "Enacting the spiritual dimension in physical education”. Physical Educator, vol. 66(4), pp. 170-179, 2009.

[14] R. Henley, Helping children overcome disaster trauma through post emergency psychosocial sports program. Boezingenstrasse: Swiss Academy for Development, 2005.

[15] R. Henley, I.C. Schweizer, F. de Gara, and S. Vetter, "How psychosocial sport \& play programs help youth manage adversity: A review of what we know \& what we should research,". International Journal of Psychosocial Rehabilitation, vol. 12, pp. 51-58, 2007.

[16] S. Nopembri, Saryono, A. Rithaudin, Pengembangan Model Pemulihan Trauma Pasca Bencana melalui Olahraga bagi Anak-anak Korban Bencana Erupsi Merapi. Laporan Penelitian Unggulan UNY 2011. Yogyakarta: Lembaga Penelitian Universitas Negeri Yogyakarta, 2011.

[17] S. Nopembri, Saryono, A. Rithaudin, Pengembangan Model Pembelajaran Pendidikan Jasmani dan Olahraga untuk Meningkatkan Keterampilan Psikososial Anak-anak di Daerah Rawan Bencana. Laporan Penelitian Fundamental. Yogyakarta: Universitas Negeri Yogyakarta, 2015.

[18] A. Rithaudin, Saryono, S. Nopembri, Evaluasi Dampak Pembelajaran Pendidikan Jasmani dan Olahraga terhadap Keterampilan Psikososial dan Spiritual Anak-anak di Daerah Rawan Bencana. Laporan Penelitian Dasar Unggulan Perguruan Tinggi. Yogyakarta: Universitas Negeri Yogyakarta, 2017 \& 2018.

[19] T.M. Egan, "Grounded Theory Research and Theory Building," Advances in Developing Human Resources, vol. 4(3), 2002. 